\title{
Analisis Keterkaitan Wilayah Peri Urban di Kabupaten Gresik dengan Wilayah Desa-Kota di Sekitarnya
}

\author{
Kartika Dwi Ratna Sari dan Eko Budi Santoso \\ Departemen Perencanaan Wilayah dan Kota, Fakultas Teknik Sipil dan Perencanaan, Institut \\ Teknologi Sepuluh Nopember (ITS) \\ e-mail:eko_budi@urplan.its.ac.id
}

\begin{abstract}
Abstrak-Wilayah peri urban merupakan wilayah dinamis yang akan terus mengalami perkembangan. Pada wilayah peri urban Gresik yang berbatasan langsung dengan Kota Surabaya dan Kota Gresik yaitu Kecamatan Cerme, Kecamatan Menganti, dan Kecamatan Driyorejo memiliki tipologi peri urban yang menunjukkan tingkat kekotaan maupun kedesaan. Tipologi wilayah peri urban tersebut dapat digunakan untuk melihat interaksi yang terjadi dengan wilayah kota maupun desa sehingga mempengaruhi perkembangan wilayah peri urban. Perkembangan tersebut dapat menimbulkan perkembangan dan pembangunan wilayah yang tidak terarah dan terkendali. Hal ini dikarenakan wilayah peri urban memiliki keterkaitan yang begitu besar dengan aspek kehidupan kota maupun desa. Karena itu, penelitian ini bertujuan untuk mengetahui hubungan keterkaitan wilayah peri urban Gresik dengan wilayah kota dan desa dilihat dari keterkaitan fisik, ekonomi, dan sosial. Teknik analisis yang digunakan adalah Analytical Network Process (ANP) yaitu metode pembobotan yang digunakan untuk mendapatkan perbandingan relatif sehingga diperoleh faktor keterkaitan yang berpengaruh terhadap tipologi wilayah peri urban yang terbentuk. Hasil akhir dari penelitian ini didapatkan bahwa pada masing-masing tipologi peri urban meliputi rural peri urban, peri urban sekunder, dan peri urban primer memiliki faktor pembentuk keterkaitan yang berbeda. Pada rural peri urban, hubungan keterkaitan yang terbentuk cenderung dengan wilayah desa. Untuk peri urban sekunder dan peri urban primer, hubungan keterkaitan yang terbentuk sebagian besar telah dipengaruhi oleh kota.
\end{abstract}

Kata Kunci-keterkaitan, peri urban, desa-kota, interaksi.

\section{PENDAHULUAN}

$\mathrm{W}$ ILAYAH peri urban (WPU) merupakan wilayah yang terletak di antara dua wilayah yang sangat berbeda kondisi lingkungannya, yaitu antara wilayah yang mempunyai kenampakan kekotaan di satu sisi dan wilayah yang mempunyai kenampakan kedesaan di sisi yang lain [1]. Adapun yang termasuk dalam wilayah peri urban Gresik adalah Kecamatan Cerme, Kecamatan Menganti, dan Kecamatan Driyorejo. Pada wilayah peri urban Gresik tersebut telah dilakukan identifikasi terkait karakteristik wilayah peri urban berdasarkan tipologinya meliputi 11 desa rural peri urban, 51 desa peri urban sekunder, dan 1 desa peri urban primer [2].

Hasil tipologi wilayah peri urban tersebut menunjukkan karakteristik wilayah peri urban berdasarkan tingkat kekotaan dan kedesaan yang dimiliki. Tingkat kekotaan dan kedesaan tersebut dapat berubah seiring perkembangan wilayah peri urban. Salah satu sifat yang dimiliki wilayah peri urban yaitu wilayah dinamis yang akan terus mengalami perkembangan. Perkembangan yang terus terjadi mengakibatkan proses perubahan pada wilayah peri urban terjadi secara acak, sendiri, dan terpisah-pisah mengakibatkan batas ruang menjadi bias. Adapun perkembangannya yang terjadi terkadang tidak mengacu pada suatu rencana tata ruang yang disepakati sehingga wilayah perdesaan mengalami transformasi yang tidak terarah dan terkendali [3]. Hal ini dapat mengakibatkan adanya wilayah yang tumbuh cepat dan terkonsentrasi pada wilayah tertentu sehingga menimbulkan kesenjangan wilayah [4].

Adapun faktor yang dapat mempengaruhi perkembangan wilayah peri urban adalah interaksi maupun keterkaitan yang terjadi pada wilayah peri urban dengan wilayah desa-kota. Hubungan keterkaitan yang terbentuk tersebut dapat berdampak positif maupun negatif [5]. Besarnya keterkaitan antar wilayah akan terlihat dari wilayah mana yang memberikan pengaruh besar terhadap wilayah peri urban, semakin besar keterkaitan yang terjadi maka semakin besar pula perkembangan yang terjadi di wilayah peri urban [6]. Interaksi ataupun keterkaitan wilayah ini dapat juga dikatakan sebagai hubungan timbal balik antar wilayah yang dapat terbentuk karena adanya hubungan yang saling mengisi (complementarity), perpindahan manusia atau barang (transferability), serta akibat dari faktor penghambat (intervening opportunity) [7].

Berdasarkan hal yang telah disebutkan diatas, pada penelitian ini akan dilakukan analisis keterkaitan wilayah peri urban di Kabupaten Gresik dengan wilayah desa-kota disekitarnya. Hal ini bertujuan untuk mengetahui faktor keterkaitan yang berpengaruh terhadap perkembangan wilayah peri urban sehingga berguna sebagai salah satu masukan bagi penyusunan kebijakan pembangunan wilayah peri urban untuk menentukan langkah yang tepat dalam mengatasi dampak akibat perkembangan wilayah peri urban. Adapun hubungan 
keterkaitan yang terbentuk nantinya dilihat dari keterkaitan fisik, ekonomi, dan sosial.

\section{METODE PENELITIAN}

Pada penelitian ini teknik analisis yang digunakan adalah Analytical Network Process (ANP). ANP merupakan suatu metode pengembangan dari AHP yang digunakan untuk pengambilan keputusan dari faktor-faktor yang saling berhubungan secara sistematik. Berbeda dengan AHP yang hanya berstruktur linear dan tidak mengakomodasikan adanya feed-back, pada ANP mengijinkan adanya interaksi dan umpan balik dari elemen-elemen dalam cluster (inner dependence) dan antar cluster (outer dependence) [8]. Inner dependence adalah hubungan antar subkriteria di dalam kriteria yang sama, sedangkan outer dependence adalah hubungan antar subkriteria di dalam kriteria yang berbeda.

Adapun tahapan dalam ANP adalah sebagai berikut:

\section{A. Menentukan struktur masalah dan tujuan penelitian}

Setelah ditentukan terkait dengan tujuan penelitian kemudian dapat menentukan faktor dan sub faktor, serta alternatif pilihan (jika diperlukan). Dalam software Super Decisions elemen faktor disebut cluster, dan elemen sub faktor disebut node. Adapun tujuan penelitian ini adalah untuk mengetahui hubungan keterkaitan wilayah peri urban dengan wilayah desa-kota, maka disusunlah variabel keterkaitan yang berpengaruh dilihat dari keterkaitan fisik, ekonomi, dan sosial.

\section{B. Menentukan hubungan antar elemen}

Untuk menentukan hubungan antar elemen yaitu antara faktor dan sub faktor yang terbentuk, dapat berupa inner dependence dan outer dependence yang disesuaikan dengan kebutuhan penelitian. Pada analisis ANP, antar sub faktor dari faktor yang berbeda dapat dihubungkan sehingga membentuk suatu jaringan. Adapun model ANP pada penelitian ini dapat dilihat pada gambar 1 berikut.

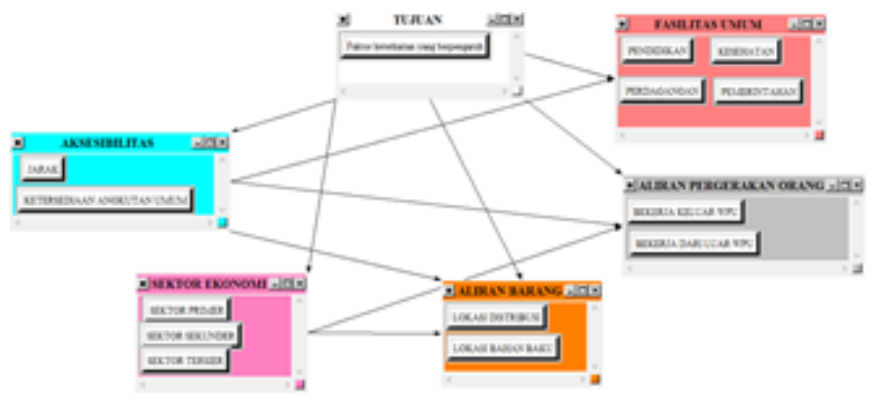

Gambar 1. Hubungan faktor dan subfaktor dalam model jaringan ANP.

Adapun penentuan inner dependence dan outer dependence didasarkan pada teori, sedangkan untuk batasannya didasarkan pada kondisi eksisting yang ada di wilayah penelitian. Berdasarkan outer dependence pada gambar diatas, jarak memberikan pengaruh terhadap aliran barang, aliran pergerakan orang, dan fasilitas umum [9]. Selain itu, untuk sub faktor ekonomi sektor primer dan ekonomi sektor sekunder memberikan pengaruh terhadap aliran barang dan aliran pergerakan orang baik untuk pendistribusian, bahan baku, maupun penyerapan tenaga kerja [7].

\section{Mengidentifikasi skala kepentingan}

Skala kepentingan setiap faktor dan sub faktor dapat diketahui menggunakan kuesioner. Langkah yang dilakukan adalah wawancara kepada stakeholders untuk mengetahui skala kepentingan setiap faktor dan sub faktor. Skala yang digunakan dalam model ANP sama dengan AHP yaitu menggunakan skala 1 sampai 9. Untuk mengetahui validitas dari penilaian yang diberikan responden, dapat dilihat dari nilai inconsistency yaitu penilaian untuk melihat apakah data tersebut konsisten. Dalam ANP meiliki standar inconsistency, dimana nilai inconsistency harus sama dengan atau dibawah 0,1 . Apabila nilai inconsistency lebih dari 0,1 maka data tersebut belum valid untuk digunakan dan perlu pengulangan [8].

\section{Software Super Decisions}

Setelah dilakukan penilaian atau judgement maka kemudian dilakukan analisis menggunakan software Super Decisions. Hasil ANP dapat dilihat pada pada tabel Cluster Matrix untuk bobot dari setiap faktor, sedangkan untuk bobot setiap sub faktor dapat diihat pada tabel Limit Matrix. Selain itu, hasil analisis menggunakan software Super Decisions dapat dilihat dari tabel Priorities dimana terdapat dua kolom yaitu kolom Limiting menampilkan bobot setiap sub faktor dari tabel Limit Matrix dan kolom Normalized by Cluster merupakan nilai bobot setiap sub faktor yang telah dinormalisasi, sehingga jumlah bobot dari setiap sub faktor dalam satu faktor yang sama adalah satu.

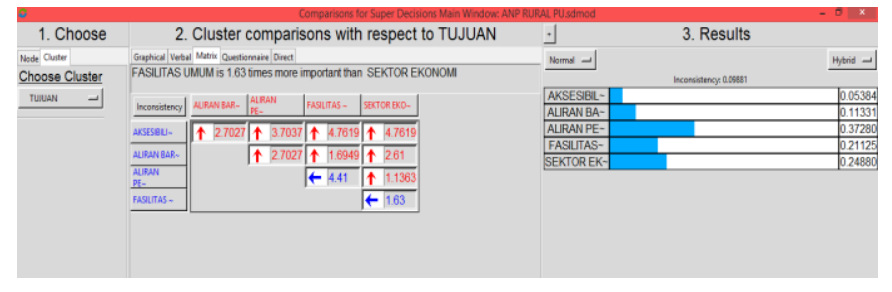

Gambar 2. Proses analisis menggunakan software Super Decisions.

Hasil dari analisis menggunakan ANP ini nantinya akan diketahui hubungan yang terbentuk pada wilayah peri urban dengan wilayah desa-kota yang ada disekitarnya, serta didapatkan bobot dari masing-masing faktor keterkaitan yang berpengaruh. Bobot ini nantinya menunjukkan tingkat peringkat faktor dan sub faktor sehingga pada masing-masing tipologi wilayah peri urban dapat memiliki peringkat dan pengaruh faktor keterkaitan yang berbeda.

\section{HASIL DAN DISKUSI}

Ruang lingkup wilayah yang digunakan pada penelitian ini adalah wilayah peri urban Gresik. Berdasarkan identifikasi karakteristik wilayah peri urban didapatkan tipologi wilayah peri urban meliputi rural peri urban, peri urban sekunder, dan peri urban primer. Dari hasil tersebut kemudian diambil sampel untuk mempresentasikan masing-masing tipologi 
sehingga diketahui bagaimana hubungan keterkaitan wilayah peri urban di Kabupaten Gresik dengan wilayah desa-kota disekitarnya dan faktor yang mempengaruhinya.

Pengambilan sampel dilakukan dengan teknik sampling probabilistik yaitu Random Sampling (pengambilan sampel secara acak) untuk menentukan wilayah desa yang mewakili dengan ukuran sampel sebanyak 30 pada masing-masing tipologi wilayah peri urban bergantung dari jumlah desa yang dihasilkan. Hal ini dikarenakan pada pengambilan sampel minimal penelitian, umumnya diambil sampel 30 untuk memperoleh hasil yang baik [10]. Namun apabila kurang dari 30 desa, maka sampel yang diambil adalah keseluruhan populasi.

Selain itu, pada penelitian ini juga menggunakan teknik non probabilistik (purposive sampling), untuk menentukan responden yang terpilih dalam pengisian kuesioner ANP dan mewakili sampel pada masing-masing tipologi. Responden yang terpilih merupakan aparat pemerintah yang mengetahui perkembangan wilayah yang ditempatinya. Dalam hal ini yang menjadi responden adalah orang yang bekerja di kantor desa di setiap sampel wilayah yang mewakilinya.

Tabel 1.

Sampel Wpu Berdasarkan Tipologinya

\begin{tabular}{cl}
\hline \hline Tipologi & \multicolumn{1}{c}{ Sampel } \\
\hline Rural Peri & 11 Desa \\
Urban & - Kecamatan Cerme: Desa Padeg, Desa Jono, Desa \\
& Pandu, Desa Dungus, Desa Lengkong, Desa Dooro, \\
& Desa Dampaan, Desa Sukoanyar. \\
& - Kecamatan Menganti: Desa Beton, Desa Pranti, Desa \\
& Gadingwatu \\
Peri Urban & 51 Desa diambil 30 Desa \\
Sekunder & - Kecamatan Cerme: Desa Banjarsari, Desa \\
& Tambakberas, Desa Cerme Lor, Desa Cerme Kidul, \\
& Desa Ngabetan, Desa Betiting, Desa Gedangkulut, \\
& Desa Wedani, Desa Kandangan, Desa Dadapkuning \\
& - Kecamatan Menganti: Desa Boboh, Desa Kepatihan, \\
& Desa Bringkang, Desa Domas, Desa Hulaan, Desa \\
& Pengalangan, Desa Menganti, Desa Laban \\
& - Kecamatan Driyorejo: Desa Bambe, Desa Mulung, \\
& Desa Tenaru, Desa Cangkir, Desa Driyorejo, Desa \\
& Kesambe Wetan, Desa Randegansari, Desa \\
& Tanjungan, Desa Karangandong, Desa Kririkilan \\
1 Desa & \\
Primer & Desa Petiken, Kecamatan Driyorejo \\
\hline \hline
\end{tabular}

Tahap selanjutnya yang perlu dilakukan adalah input penilaian respoden dari kuesioner ke dalam software Super Decisions. Akan tetapi pada software Super Decisions ANP untuk mendapatkan bobot dari setiap faktor penilaian responden perlu dilakukan perhitungan rata-rata geometric (geometric mean) dari hasil pengisian kuesioner. Adapun hasil analisis yang didapatkan adalah sebagai berikut.

\section{A. Rural Peri Urban}

Pada wilayah rural peri urban keterkaitan yang terbentuk cenderung dengan wilayah perdesaan, dikarenakan pada wilayah rural peri urban belum terkena dampak dari perkembangan perkotaan. Hubungan keterkaitan yang terjadi hanya disekitar wilayah desa yang letaknya berdekatan dengan wilayah rural peri urban. Adapun faktor keterkaitan paling berpengaruh pada wilayah rural peri urban adalah sebagai berikut.

1. Pada faktor aliran barang, sub faktor yang paling berpengaruh adalah lokasi distribusi dikarenakan keterkaitan yang terbentuk akibat dari pendistribusian hasil pertanian ke wilayah lain di sekitar wilayah rural peri urban. Misalnya seperti pada wilayah Desa Padeg di Kecamatan Cerme letaknya yang berdekatan dengan Kecamatan Kedamean, mengakibatkan wilayah tersebut memiliki hubungan dengan wilayah desa yang ada di Kecamatan Kedamean dibandingkan dengan wilayah Kota Gresik maupun Kota Surabaya.

2. Pada wilayah rural peri urban terkait dengan fasilitas umum, sub faktor yang memberikan pengaruh paling besar adalah fasilitas pendidikan, dikarenakan umumnya pada wilayah rural peri urban hanya terdapat pendidikan hingga tingkat SD sehingga untuk mengakses pendidikan jenjang lebih tinggi harus ke wilayah lainnya. Misalnya seperti yang terdapat pada Desa Dooro dan Desa Dungus untuk mengakses pendidikan tingkat SMP dan SMA terlayani di Desa Lengkong.

3. Dari kedua sub faktor aliran pergerakan orang, yang memberikan pengaruh paling besar adalah penduduk yang bekerja keluar wilayah peri urban. Hal ini dikarenakan jumlah penduduk yang bekerja keluar wilayah rural peri urban cukup banyak sehingga mempengaruhi hubungan keterkaitan wilayah tersebut dengan wilayah lainnya.

4. Sub faktor yang memberikan pengaruh paling besar pada sektor ekonomi adalah sektor primer yaitu pertanian. Hal ini dikarenakan pada wilayah rural peri urban mayoritas masih terdapat lahan pertanian baik sawah yaitu pertanian tanaman pangan maupun perikanan budidaya tambak. Adanya sektor primer ini nantinya yang berpengaruh tehadap keterkaitan dengan wilayah lainnya.

Tabel 2

.Bobot Faktor dan Subfaktor Rural Peri Urban

\begin{tabular}{|c|c|c|}
\hline Tipologi & Faktor dan Subfaktor & Bobot Faktor \\
\hline $\begin{array}{l}\text { Rural Peri } \\
\text { Urban }\end{array}$ & $\begin{array}{l}\text { Aksesibilitas (0.053839) } \\
\text { Subfaktor: } \\
\text { a. Jarak (0.82457) } \\
\text { b. Ketersediaan Angkutan Umum (0.17543) } \\
\text { Sektor Ekonomi }(0.113312) \\
\text { Subfaktor: } \\
\text { a. Ekonomi Sektor Primer }(0.75338) \\
\text { b. Ekonomis Sektor Sekunder }(0.14250) \\
\text { c. Ekonomi Sektor Tersier }(0.10413) \\
\text { Aliran Barang (0.372795) } \\
\text { Subfaktor: } \\
\text { a. Lokasi Distribusi }(0.70513) \\
\text { b. Lokasi Bahan Baku }(0.29487) \\
\text { Aliran Pergerakan Orang }(0.211250) \\
\text { Subfaktor: } \\
\text { a. Bekerja Keluar WPU }(0.82408) \\
\text { b. Bekerja Dari Luar WPU }(0.17592) \\
\text { Fasilitas Umum (0.248803) } \\
\text { Subfaktor: } \\
\text { a. Fasilitas Pendidikan }(0.41504) \\
\text { b. Fasilitas Kesehatan }(0.30767) \\
\text { c. Fasilitas Perdagangan }(0.16027) \\
\text { d. Fasilitas Pemerintahan }(0.11702)\end{array}$ & 1 \\
\hline
\end{tabular}

Sumber: Hasil Analisis, 2017 
5. Pada faktor aksesibilitas menjadi faktor keterkaitan yang paling rendah pengaruhnya, karena kondisinya mayoritas masih minim baik dari dari segi jalan maupun angkutan umum. Oleh karena itu, hubungan yang terjadi cenderung dengan wilayah disekitarnya baik wilayah dalam peri urban maupun rural dibandingkan wilayah urban.

\section{B. Peri Urban Sekunder}

Pada wilayah peri urban sekunder keterkaitan yang terbentuk cenderung dengan wilayah peri urban maupun wilayah perkotaan. Hal ini menunjukkan bahwa pada wilayah peri urban sekunder telah terkena dampak dari perkembangan perkotaan. Adapun faktor paling berpengaruh adalah aliran barang, namun nilai bobot aliran barang pada wilayah peri urban sekunder berbeda dengan rural peri urban. Pada peri urban sekunder nilainya lebih besar yaitu 0.408746 , sedangkan pada rural peri urban nilainya hanya 0.372795 . Hal ini dikarenakan pada wilayah peri urban sekunder aliran barang yang terjadi tidak hanya pendistribusian sektor primer tetapi juga dari sektor sekunder. Untuk lebih jelasnya terkait faktor dan subfaktor berpengaruh dapat dilihat pada tabel 3 .

Tabel 3.

Bobot Faktor dan Subfaktor Peri Urban Sekunder

\begin{tabular}{|c|c|c|}
\hline Tipologi & Faktor dan Subfaktor & Bobot Faktor \\
\hline $\begin{array}{l}\text { Rural Peri } \\
\text { Urban }\end{array}$ & $\begin{array}{l}\text { Aksesibilitas }(0.186980) \\
\text { Subfaktor: } \\
\text { a. Jarak (0.80843) } \\
\text { b. Ketersediaan Angkutan Umum }(0.19157) \\
\text { Sektor Ekonomi }(0.080730) \\
\text { Subfaktor: } \\
\text { a. Ekonomi Sektor Primer }(0.23236) \\
\text { b. Ekonomis Sektor Sekunder }(0.49422) \\
\text { c. Ekonomi Sektor Tersier }(0.22252) \\
\text { Aliran Barang }(0.408746) \\
\text { Subfaktor: } \\
\text { a. Lokasi Distribusi }(0.78696) \\
\text { b. Lokasi Bahan Baku }(0.21304) \\
\text { Aliran Pergerakan Orang }(0.111092) \\
\text { Subfaktor: } \\
\text { a. Bekerja Keluar WPU }(0.67912) \\
\text { b. Bekerja Dari Luar WPU }(0.32088) \\
\text { Fasilitas Umum }(0.212451) \\
\text { Subfaktor: } \\
\text { a. Fasilitas Pendidikan }(0.52902) \\
\text { b. Fasilitas Kesehatan }(0.19807) \\
\text { c. Fasilitas Perdagangan }(0.18553) \\
\text { d. Fasilitas Pemerintahan }(0.08737)\end{array}$ & 5 \\
\hline
\end{tabular}

Sumber: Hasil Analisis, 2017

Berdasarkan tabel diatas, diketahui bahwa:

1. Pada faktor aliran barang, sub faktor yang memberikan pengaruh paling besar adalah sub faktor lokasi distribusi. Sub faktor lokasi distribusi yang besar tersebut dipengaruhi oleh adanya sektor primer, sektor sekunder, maupun adanya jarak yang dekat dengan wilayah kota yaitu Kota Surabaya maupun Kota Gresik sebagai lokasi distribusinya. Adanya lokasi distribusi inilah yang mengakibatkan hubungan keterkaitan pada peri urban sekunder terjadinya dengan wilayah urban. Adapun untuk Kecamatan Menganti dan Kecamatan Driyorejo cenderung memiliki hubungan dengan Kota Surabaya, sedangkan untuk Kecamatan Cerme cenderung dengan Kota Gresik.
2. Pada faktor fasilitas, sub faktor yang memberikan pengaruh besar adalah sub faktor fasilitas pendidikan. Dikarenakan tidak hanya keterkaitan keluar wilayah peri urban untuk mengakses fasilitas pendidikan, tetapi sesama wilayah peri urban sekunder maupun dari luar peri urban sekunder juga mengakses fasilitas pendidikan yang ada. Hal inilah yang mengakibatkan keterkaitan yang terbentuk tidak hanya dari luar tetapi juga di dalam wilayah peri urban. Misalnya seperti pada Desa Menganti fasilitas pendidikan yang ada sampai tingkat SMA juga digunakan untuk melayani Desa Hulaan, Desa Domas, dan sebagainya.

3. Faktor aksesibilitas memberikan pengaruh paling besar adalah jarak, dimana jarak dengan wilayah urban cenderung lebih dekat dan lebih mudah aksesnya. Adapun untuk Kecamatan Menganti dan Kecamatan Driyorejo cenderung memiliki hubungan dengan Kota Surabaya, sedangkan untuk Kecamatan Cerme cenderung dengan Kota Gresik.

4. Pada faktor aliran pergerakan orang, subfaktor penduduk yang bekerja keluar wilayah peri urban memberikan pengaruh lebih besar dikarenakan meskipun terdapat sektor sekunder yang dapat menarik penduduk yang dari luar wilayah peri urban tetapi jumlah penduduk yang keluar untuk bekerja antar wilayah peri urban sekunder maupun di Kota Gresik dan Kota Surabaya masih lebih besar.

5. Pada faktor sektor ekonomi, sub faktor yang memberikan pengaruh lebih besar adalah sektor sekunder. Sektor sekunder memberikan pengaruh dikarena pada peri urban sekunder terdapat banyak pabrik ataupun industri. Misalnya pada wilayah desa di Kecamatan Driyorejo banyak terdapat jumlah industri dibandingkan wilayah peri urban sekunder lainnya. Namun sektor primer dan sektor tersier masih memberikan pengaruh meskipun tidak terlalu berdampak dibandingkan sektor sekunder. Adanya sektor sekunder inilah yang nantinya dapat memicu hubungan interaksi ataupun keterkaitan yang terbentuk dari lokasi distribusi maupun penyerapan tenaga kerja dari sektor ekonomi yang memberikan pengaruh besar.

\section{Peri Urban Primer}

Pada wilayah peri urban primer keterkaitan yang terbentuk cenderung dengan wilayah perkotaan. Hal ini menunjukkan bahwa pada wilayah peri urban primer telah terkena dampak dariman peri urban primer yang menjadi faktor paling berpengaruh adalah aliran barang. Namun dari ketiga klasifikasi tersebut memiliki bobot yang berbeda. Bobot faktor aliran barang pada peri urban primer memberikan nilai paling besar yaitu 0.462340 . Hal ini dikarenakan pada peri urban primer aliran barang yang terjadi telah didukung oleh faktor lainnya seperti aksesibilitas maupun dari sektor primer dan sektor sekunder. Kondisi aksesibilitas pada wilayah peri urban primer dari segi jarak dekat dengan Kota Surabaya dan banyak dilewati oleh trayek angkutan umum. Adapun faktor keterkaitan paling berpengaruh pada wilayah rural peri urban adalah sebagai berikut.

1. Pada faktor aliran barang, sub faktor yang memberikan pengaruh besar adalah sub faktor lokasi distribusi yang mengakibatkan hubungan keterkaitan pada peri urban primer dengan wilayah kota. Selain itu, pada Desa Petiken 
terdapat pusat pertokoan yang dijadikan sebagai lokasi distribusi dari wilayah lainnya.

2. Pada faktor aliran pergerakan orang juga memberikan pengaruh besar yang disebabkan banyaknya penduduk yang bekerja keluar wilayah peri urban primer yaitu ke wilayah peri urban maupun Kota Surabaya. Tetapi paling banyak ke Kota Surabaya, hal ini didukung dengan adanya permukiman baru Perumnas dari perkembangan Kota Baru Driyorejo dimana sebagian besar penduduknya adalah bukan penduduk setempat tetapi penduduk ulang alik yang bekerja di Kota Surabaya maupun wilayah lain. Pada wilayah Gresik memang terdapat banyak penduduk ulang alik sehingga mempengaruhi pergerakan dan perkembangannya [11].

3. Pada faktor aksesibilitas, sub faktor yang memberikan pengaruh besar adalah sub faktor jarak yaitu jarak yang dekat dengan Kota Surabaya. Selain itu, pada wilayah peri urban primer juga telah dilewati trayek angkutan umum menuju wilayah urban yaitu Kota Surabaya.

4. Sub faktor fasilitas pendidikan memberikan bobot paling besar dalam faktor fasilitas umum dikarenakan terjadi keterkaitan keluar wilayah peri urban untuk mengakses fasilitas pendidikan yaitu dengan Kota Surabaya untuk jenjang pendidikan tingkat SMA.

Tabel 4.

Bobot Faktor dan Subfaktor Peri Urban Primer

\begin{tabular}{|c|c|c|}
\hline Tipologi & Faktor dan Subfaktor & Bobot Faktor \\
\hline $\begin{array}{c}\text { Rural Peri } \\
\text { Urban }\end{array}$ & $\begin{array}{l}\text { Aksesibilitas (0.122901) } \\
\text { Subfaktor: } \\
\text { a. Jarak (0.99466) } \\
\text { b. Ketersediaan Angkutan Umum }(0.20534) \\
\text { Sektor Ekonomi }(0.042393) \\
\text { Subfaktor: } \\
\text { a. Ekonomi Sektor Primer }(0.20435) \\
\text { b. Ekonomis Sektor Sekunder }(0.61656) \\
\text { c. Ekonomi Sektor Tersier }(0.17909) \\
\text { Aliran Barang (0.462340) } \\
\text { Subfaktor: } \\
\text { a. Lokasi Distribusi }(0.81105) \\
\text { b. Lokasi Bahan Baku }(0.18895) \\
\text { Aliran Pergerakan Orang }(0.278517) \\
\text { Subfaktor: } \\
\text { a. Bekerja Keluar WPU }(0.86868) \\
\text { b. Bekerja Dari Luar WPU }(0.13132) \\
\text { Fasilitas Umum (0.093850) } \\
\text { Subfaktor: } \\
\text { a. Fasilitas Pendidikan }(0.58988) \\
\text { b. Fasilitas Kesehatan }(0.19544) \\
\text { c. Fasilitas Perdagangan }(0.15978) \\
\text { d. Fasilitas Pemerintahan }(0.05491)\end{array}$ & 4 \\
\hline
\end{tabular}

Sumber: Hasil Analisis, 2017

5. Pada faktor sektor ekonomi, subfaktor ekonomi sektor sekunder memberikan pengaruh besar. Hal ini dikarenakan pada wilayah peri urban primer banyak penduduknya yang bekerja di sektor sekunder, meskipun terdapat di wilayah lain namun sektor sekunder inilah yang mengakibatkan terjadinya interaksi ataupun keterkaitan dengan wilayah lainnya terutama dengan Kota Surabaya.

Dari hasil analisis keterkaitan ketiga tipologi wilayah peri urban diatas diketahui bahwa masing-masing tipologi memiliki kecenderungan hubungan keterkaitan yang berbeda. Untuk wilayah rural peri urban cenderung memiliki hubungan keterkaitan dengan wilayah desa yaitu wilayah disekitar wilayah rural peri urban baik wilayah di Kecamatan lain maupun di dalam wilayah peri urban. Untuk peri urban sekunder dan primer cenderung telah memiliki hubungan ketekaitan dengan wilayah kota yaitu Kota Gresik dan Kota Surabaya. Selain itu, untuk wilayah peri urban sekunder juga dipengaruhi oleh keterkaitan dengan wilayah peri urban sekunder lainnya, dan peri urban primer lebih besar keterkaitan dengan Kota Surabaya dibandingkan Kota Gresik.

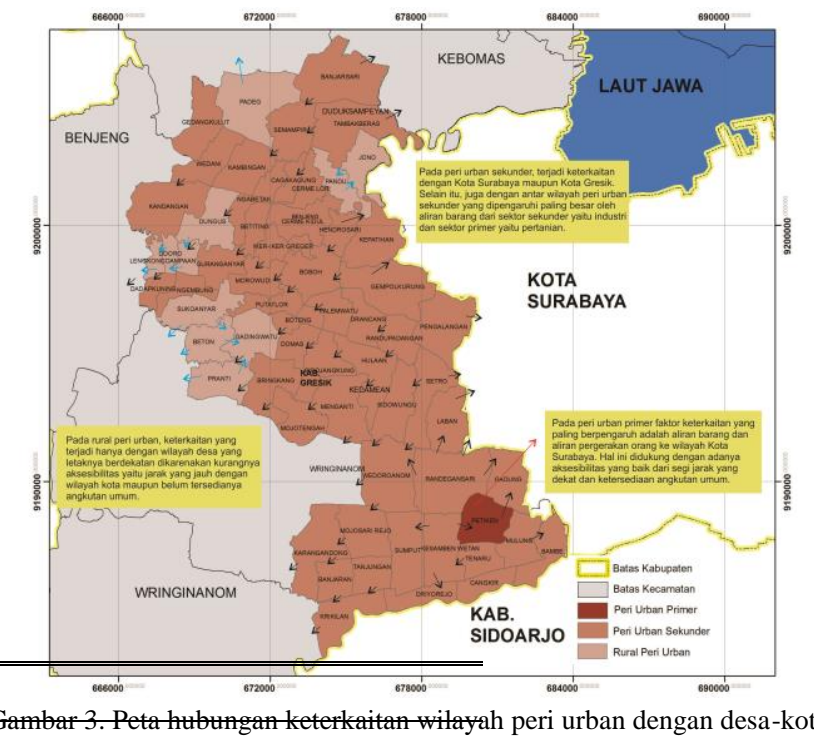

Berdasarkan gambar diatas, dapat dilihat bahwa terkait dengan faktor dan subfaktor yang mempengaruhi masingmasing wilayah tipologi peri urban berbeda. Hal ini dikarenakan memiliki bobot yang berbeda yang menunjukkan besar pengaruhnya. Misalnya saja faktor aksesibilitas pada wilayah rural peri urban tidak memberikan pengaruh keterkaitan. Tetapi pada wilayah peri urban sekunder dan peri urban primer, faktor aksesibilitas memberikan pengaruh yang besar dengan tingkat peringkat 3 dikarenakan hubungan keterkaitan wilayah tersebut dengan wilayah perkotaan telah didukung oleh aksesibilitas baik jarak dengan wilayah urban yang dekat maupun ketersediaan angkutan umum.

\section{KESIMPULAN/RINGKASAN}

Berdasarkan hasil dan diskusi, didapatkan, keterkaitan yang terjadi pada wilayah peri urban Gresik adalah hubungan yang saling mengisi yang dapat mempengaruhi perkembangan yang terjadi pada wilayah peri urban tersebut. Namun pada masingmasing tipologi memiliki kecenderungan hubungan dengan desa-kota, serta bobot dan peringkat yang berbeda terhadap faktor keterkaitan berpengaruh.

1. Pada faktor aliran barang memberikan pengaruh paling besar terhadap ketiga tipologi wilayah peri urban dengan bobot yang berbeda. Hal ini menunjukkan bahwa pengaruh aliran barang yang besar juga bergantung pada tingkat kekotaan suatu wilayah, terbukti dari bobotnya yang besar pada peri urban primer.

2. Pada faktor aliran pergerakan orang, pergerakan penduduk 
keluar wilayah peri urban memberikan pengaruh yang besar dikarenakan untuk bekerja. Pada rural peri urban cenderung bekerja ke Kota Gresik, sedangkan pada peri urban sekunder dan primer penduduknya cenderung bekerja ke Kota Surabaya.

3. Pada faktor fasilitas umum, keterkaitan yang terjadi untuk mengakses fasilitas sehingga antar wilayah saling melengkapi baik fasilitas pendidikan, fasilitas kesehatan, fasilitas perdagangan, maupun fasilitas pemerintahan.

4. Pada faktor aksesibilitas terjadi perbedaan pengaruh, dimana untuk rural peri urban faktor ini memberikan pengaruh paling rendah dibandingkan pada peri urban sekunder dan peri urban primer. Hal ini dikarenakan kondisinya yang minim yaitu jarak yang jauh dengan wilayah kota dan belum tersedianya angkutan umum pada wilayah rural peri urban.

5. Pada faktor sektor ekonomi terdapat kecenderungan yang berbeda, dimana pada wilayah rural peri urban mayoritas dipengaruhi oleh sektor primer namun pada peri urban sekunder dan peri urban primer telah dipengaruhi sektor sekunder dari adanya industri.

\section{DAFTAR PUSTAKA}

Depan Kota. Yogyakarta: Pustaka Pelajar, 2008.
K. D. R. dan E. B. S. Sari, "Determination of Peri Urban Typology Based on Physics, Economic, and Social Aspects in Gresik Regency (Periodical style-Submitted for publication)," 2017.

[3] D. Maryonoputri, L. D., Firman, T. dan Hudalah, "Karakteristik Wilayah Peri-Urban pada Metropolitan Jabodetabekju," Pap. Reg. Plan. Res. Gr. ITB, vol. 2, 2012.

[4] V. K. dan E. B. S. Siswanto, "Penentuan Kesenjangan Ekonomi Wilayah Berdasarkan Tipologi Peri Urban di Kabupaten Sidoarjo," J. Tek. POMITS, pp. 1-5, 2012.

[5] A. W. Iaquinta, D. L. dan Drescher, Defining Periurban: Understanding Rural-Urban Linkage and Their Connection to Institusional Contexts. Rio de Janeiro: International Rural Sociology Association, 2000.

[6] J. Jati, V. I. M. dan Christanto, "Kajian Perkembangan Permukiman Wilayah Peri Urban Di Sebagian Wilayah Kabupaten Sukoharjo Tahun 2001-2007," Universitas Gajah Mada, 2011.

[7] K. M. Kasikoen, "Keterkaitan Antar Wilayah (Studi Kasus: Kabuapten Cilacap)," J. Planesa, vol. 2, pp. 146-153, 2011.

[8] A. Rusydiana, A. S. dan Devi, Analytic Network Process: Pengantar Teori dan Aplikasi. Bogor: SMART Publishing, 2013.

[9] U. Farida, "Pengaruh Aksesibilitas Terhadap Karakteristik Sosial Ekonomi Masayarakat Pedesaan Kecamatan Bumijawa Kabupaten Tegal," J. Wil. dan Lingkung., vol. 1, pp. 49-66, 2013.

[10] U. Sekaran, Metode Penelitian Bisnis. Jakarta: Salemba Empat, 2006.

[11] A. G. dan E. B. S. Aulia, B. U., "Green Open Space Provision Evaluation in Gresik Urban Areas Through Carbon Footprint Approach," in International Congress of Asian Planning Schools Association UTM, 2015. 